\title{
LARRY SJAASTAD, THE LAST CHICAGOAN
}

\author{
by \\ Kenneth W Clements ${ }^{1}$ \\ Economics Program \\ The University of Western Australia
}

1 This paper is based on a speech I gave at the dinner of the Conference on FTAs, organised by the Trade, Migration and Development Research Centre, The University of Western Australia, 6 July 2004. I have benefited from comments from and discussions with Bill Dougan, Irene Glasner, Izan, Paul Miller and Larry Sjaastad. I thank Mei Han for research assistance and Jim Lothian for encouragement. 
In 2004 Larry Sjaastad retired after 42 years from teaching economics at The University of Chicago. This paper marks that occasion by providing some little-known biographical information about Larry, discusses his research, activities in Latin America, his role as a teacher, his place in Chicago economics, and Larry as a person. In what follows, I draw on a book of letters from 72 of Larry's former students and colleagues that was presented to him in July 2004 at The University of Western Australia (Clements and Tcha, 2004a,b); these letters provide considerable insight into Larry and his career.

\section{From Where Did Larry Come?}

Larry was born in 1934 into strong Viking stock in North Dakota. All four of his grandparents migrated from Norway in the 1880s. Frank Knight, Ted Schultz and Gale Johnson, all great Chicago economists, grew up on farms in the back blocks of the Mid West, and the same was true of Larry who started life on the family farm in North Dakota.

Like many farm boys, his father allocated to him some land to grow a crop on the basis that you do all the work, and then you get to keep the proceeds after expenses have been covered. I suppose that it was a bit like rural Australia and that most farm boys in North Dakota bought fishing rods, rifles and motor bikes with their new found wealth. Not Larry however, who showed an early creative interest by using the money from his flax crop to buy a typewriter, to do some serious writing.

After high school came studies in electrical engineering at North Dakota Agricultural College where Larry continued his interest in writing, by contributing to the student newspaper. Those who have spoken to Larry about how computers really work, or better still, the theory of electricity, know that he has a special understanding of these matters -- it all originated from the NDAC.

Then came what eventually turned out to be a very fortunate event, but at the time must have seemed catastrophic: Larry adopted a rather questioning attitude to the college administration that probably had a bit of a biting tone to it; those who know Larry will be able to imagine what it would have been like! After a senior faculty member laid down the law about what he could and could not do, and possibly what he could and could not think, Larry decided that enough was enough, and simply left North Dakota Agricultural College halfway through his electrical engineering studies. This occurred in the mid 50s, around the time of McCarthyism with rampant allegations of non-American activities, communism etc., and Larry was a victim of that unfortunate period. 
In any event, it was probably a good thing for economics that Larry left North Dakota early in life, as he then landed a scholarship to go The University of Chicago, where he did a BA, MA and PhD. Working with Al Harberger, Margaret Reid and Ted Schultz, Larry's thesis was path-breaking extension of human capital theory. He analysed the decision to migrate by comparing the costs of forgone earnings in the origin location with the discounted present value of higher expected earnings to be had in the destination.

In a letter to Larry from his colleague Bob Lucas, Bob described the thesis this way:

You and I were both students of Al Harberger and Gregg Lewis, and I remember that both of them used you as an example for later cohorts of what it meant to be a successful $\mathrm{PhD}$ student. Gregg especially admired the mix of theory, careful empirical work, and substantive interest of your thesis, and held it up as a level of research achievement that we should aspire to. In this as in so many other matters, I think Gregg's taste turned out to be pretty good. ${ }^{2}$

The thesis led to the seminal article "Costs and Returns of Human Migration", published in the Journal of Political Economy in 1962 (Sjaastad, 1962). This is probably the most widely cited article in the area, and even just since 1987 it has attracted more than 250 citations, the hallmark of a truly influential work.

Larry's first academic job was at the University of Minnesota, where he was very close to Anne Krueger, who is now the First Deputy Managing Director of the IMF. He then led the first program in Latin America under President Kennedy's Alliance for Progress Program; indeed, it was always noted as "la1". That program was at the National University of Cuyo, in Mendoza, Argentina. In 1962 Larry returned to Chicago, where he has been ever since.

\section{Contributions in Public Finance and International Economics}

In addition to the migration work, Larry has made lasting research contributions in several other areas, most importantly public finance and international economics.

In his 1977 JPE article with Daniel Wisecarver "The Social Cost of Public Finance" (Sjaastad, 1977), Larry developed a highly innovative normative theory of government that relates to all aspects of taxation and spending policies. This is a comprehensive theory which shows in a very neat manner exactly how all elements of public finance are related and hang together.

\footnotetext{
${ }^{2}$ This letter, and the others from which I quote below, are from Clements and Tcha (2004a,b).
} 
For many years, a key concern in international trade was the analysis of the effects of systems of trade taxes and subsidies. Larry invented a new concept of protection that substantially advanced understanding of the issues with "true protection". This was a great idea that showed in a very simple manner, just what trade taxes did to raise costs in general. It was this rise in costs that was the key to understanding how import protection had the unintended consequences of punishing the country's own exporters -- they were landed with the higher costs and simply couldn't pass them on in the form of higher prices, so they end up getting squeezed. Larry has published a number of papers on this topic, but the key reference is Sjaastad (1980). True protection caught on like wildfire, especially in Latin America because of the power of the idea, and because it was just what economists wanted in situations where the problem is important and detailed reliable data are missing. This research was also influential in some developed economies such as Spain, as is indicated by the following quotation from a letter from Alfonso Carbajo:

Few people know that Larry played a crucial role in setting the path for economic reform in Spain in the late seventies and early eighties. In those years, a small group of reformers in the Ministry of Trade drew on his research on commercial policy, particularly on his findings of protection as a tax on exports, to make a case for dismantling trade barriers. All the time, expansion of exports was a widely held political objective, and Larry's research provided nice ammunition to head off protectionist pressures. Then, in the early eighties, both in formal presentations and in informal discussions, Larry himself forcefully conveyed to leading officials and politicians the advantages of radical economic reform. Larry, many of the political actors of that period now think that, thanks to your insights back then, the road toward economic efficiency in this country has been much less bumpier than it could have been otherwise.

One other aspect of true protection is worth mentioning. The nomenclature "true protection" was a truly brilliant marketing devise as it immediately conjures up the idea that all other measures of protection are false. ${ }^{3}$

In recent years, Larry and his students have been working on a simple but highly sophisticated general-equilibrium model of exchange rates and prices for all major countries in the world, and how changes in one exchange rate are transmitted around the world. The most recent installment of this work is his paper "Preferential Trading

\footnotetext{
${ }^{3}$ Perhaps this explains why Max Corden was hostile to the idea.
} 
Agreements and Exchange Rate Regimes", presented at the UWA Conference on FTAs, that relates to the inevitable consequences of changes in third-country exchange rates for real exchange rates and interest rates in countries joining what Larry calls a "DTA", a discriminatory trade agreement. ${ }^{4}$

\section{Influence in Latin America}

Ever since working at Mendoza in the early 1960s, Larry has had strong ties with Latin America in the form of research, teaching and students from the region at Chicago. Together with Al Harberger, Larry organised the highly productive Latin American Workshop at Chicago, at which students and visitors presented research on LA topics. Larry has strong professional contacts with Chile and Argentina in particular, and such is his knowledge of, and influence in, Latin America that he is treated almost as a god when he visits, certainly a guru.

The following two quotes from letters serve to give a flavour of Larry's role in Latin America:

Your efforts remain visible, and will remain visible, as Latin American countries move haltingly towards more liberal, pro-growth policies. It was a long struggle to break with the Prebisch tradition. You can be proud that your contributions had a major impact on making that transition possible.

Allen H. Meltzer

You have made an impact on economists and friends in all the continents. But first and perhaps mostly in Latin America where "the Chicago boys" became known for their evangelical spread of the wisdom of free markets, laissez-fare and economic stability.

The "Chicago boys" were sometimes associated with Milton Freidman. However, I once heard our friend Al Harberger complain: "The Chicago boys are my boys!" He was right! But without Larry Sjaastad, who was, at the beginning at least, Al's lieutenant, Chicago's impact on Latin America would have been much less.

Robert Mundell

${ }^{4}$ Other contributions by Larry to the topic of prices and exchange rates for all major countries include Sjaastad (1989, 1990, 1996, 1998a,b. 1999, 2000, 2001, 2003). 


\section{$\underline{\text { Larry and Students }}$}

The research that I described above is well known to the economics profession. What is less well known to those outside of Chicago is Larry's activities with students. At Chicago, everyone does considerable teaching, and effective teaching is greatly admired by all at the University. Interestingly, the luminaries such as Becker, Friedman and Harberger were simply dazzling in the classroom. Within this context with the bar raised so high, many students still felt that Larry was one of the best teachers at Chicago. His courses were highly sought after and he taught high-level analytical material that was motivated by realworld considerations. Larry's special talent was to be able to make the material accessible to a large number of students, and to emphasise intuition and fundaments, not the latest fad -- it was a question of old truths, rather than new falsehoods.

At Chicago, Larry supervised no less than $139 \mathrm{PhD}$ dissertations over 42 years, which must account for something like 20 percent of all $\mathrm{PhDs}$ in economics that finished at Chicago during that time. On average, that represents supervising to completion 3.3 students per year, an astonishing achievement way beyond the capabilities of most. The names and thesis titles of these students are contained in the Appendix. The substantial diversity of the topics of the theses is a genuine reflection of the breadth of Larry's expertise in economics.

Many of the letters from former students allude to the life-changing experience of being taught by Larry, being exposed to his seriousness of purpose in economics, his generosity to students, his exceptional sense of fun, and his outstanding qualities as a human being. The following quotations from letters from former students provide a feel for these sentiments:

The greatest privilege anybody can experience as an economics student is the opportunity to attend the University of Chicago, especially in those golden years when Nobel prizes were being incubated. Within the economics department of the University one of the sharpest minds belonged to Larry Sjaastad, who achieved the rare simultaneity of being a great economist and a clear expositor.

...[W]ithout any doubt the best showcase of Larry's educational virtues were his lectures. Almost without exception Chicago lecturers were fabulous -- no tolerance in Chicago to indifference towards poor class performance in favour of an exclusive concentration on research and publications -- but Larry stood out among the best. His 
lectures were thoroughly prepared and careful presented; class notes were easy to take and became eternal treasures.

Francisco Gil Díaz

I am not exaggerating in saying that he was the professor from whom I learned the most important lesson: the enjoyment of economics as a profession. Larry's classes added an enormous and useful set of tools that I continue using in my professional life. Larry has a way of making everything he taught challenging and interesting.

Carlos Alfredo Rodriguez

Before taking your class, I had as much difficulty reconciling the Keynesian and neoclassical approaches as most other people. Macroeconomics had always struck me as more a matter of choosing sides than synthesizing knowledge. You showed my classmates and I how everything fit together, to the point of being able to build a neoclassical edifice with Keynesian bricks. Moreover, you performed this feat so effortlessly that it seemed to us students as if we had done it ourselves. This is truly brilliant teaching, which I have quite shamelessly and most imperfectly mimicked over several decades.

Bill Dougan

I still recall the clarity with which you expressed the macroeconomics that was so hard for those of us with limited training. It was a revelation and you were the magician. I confess I used many of your ideas when I taught my own macroeconomics courses. But I guess that is what happens to good teachers: their ideas are promptly cribbed by their students. At least that is how I rationalize my theft!

Steve Easton

Like so many others, I had come to Chicago lured by the prospect of studying at the department made famous by the likes of Milton Friedman and George Stigler. Taking his class, I remember at the time being most impressed by Larry's ability to smoke and teach simultaneously. Looking back from a vantage of two decades, I realize I learned more in his class than any other. Most importantly, I learned that economics mattered and was worth taking seriously.

John Devereux 


\section{The Last Chicagoan}

As mentioned before, Larry's type of economics is analytical yet applied, and is always motivated by just trying to understand the way the world works. Larry used to be closely associated with Al Hargerber, Harry Johnson and Bob Mundell when they were at Chicago -- economists who had something interesting to say about almost everything in economics. This of course is canonical Chicago economics.

For good or bad, the era in which this sort of economics is vigorously practiced at Chicago seems to be drawing to a close. This is a bit ironic, as the demand for this style of economics has never been stronger. In any event, new Chicagoans now seem to have a less distinctive style (a reflection of globalisation?), and are possibly now less influential. As Larry is the last one left of this group, I think it is legitimate to call him "The Last Chicagoan" -- the Last Old Chicagoan. Some of the letters in the book have something interesting to say about the passing of Old Chicago. For example:

I think of my days at Chicago as being on the cusp -- a time where the policy relevance of economics (which is why I wanted to study economics in the first place) was giving way to the mathematics of economics. While the profession may one day come back around to its more worldly roots, I wanted to tell you how inspirational you were to me...Y Your courses remain guiding posts.

Kenneth M. Miranda

You are one of the last exponents of a style of economics at which The University of Chicago excelled for decades, a tradition that has been superseded by a new paradigm that tries to understand simple properties of economies using models based on representative agents choosing optimal programs in an infinite horizon. And while I benefited also from learning this modern approach in my days at Chicago, I cannot help often ask what do young applied economists, who are not as lucky as I was, being exposed to masters of both approaches, do today to fill the gap and disentangle the unlimited questions that come to their desk in their daily work.

Edgardo Favaro

When I think back to those years at The University of Chicago I realize that it was from you that I learned everything of practical relevance in graduate school. In an academic environment where the emphasis was so skewed towards theoretical issues it was refreshing to sit in your 
courses and glide towards reality. Monetary policy, exchange rate regimes, development issues, in your teachings lost their abstract bearing and assumed a relevance that was to me of the utmost importance as an economist at the International Monetary Fund, at the European Central Bank, and in financial markets. Formal models in your classes were related to the nuts and bolts of an actual economic system in a way that was intellectually challenging and extremely useful...[Y]our teaching has been precious, far more than some now forgotten models which at the time represented the latest fad.

Fabio Scacciavillani

It's an understatement to say that you stand among the very few top ranked economists in the world. The department is losing its best economist, one who is devoted to economics in its truest sense. I want to thank you personally for so many jobs well done as we have shared thesis committees and workshop activities together, and for so many fruitful intellectual interchanges. You are my most valued colleague. Darn you for retiring!

George Tolley

\section{Larry the Larrikin}

No account of Larry and his activities would be complete without something about "Larry the person". Larry has a strong personality and puts his ideas forcefully. He is a relentless debater and awesome when in full flight at a Chicago workshop or elsewhere -especially if he thinks the presenter is talking nonsense! Larry is unpretentious in his style, and has a particular dislike of pomposity. While he has great seriousness of purpose in his work, at the same time Larry is kind and generous to anyone who genuinely wants to learn. For the last two decades he has been the primary carer of his wife Irene who suffered a stroke; he is devoted to Irene and I have never heard him complain of his onerous responsibilities.

Additionally, Larry has irreverence for authority, which no doubt helps when dreaming up all those creative ideas which challenge orthodoxy. He also has a great sense of style and fun, which Australians would affectionately refer to as "larrikinism". These dimensions of Larry's nature are clearly revealed in the following three quotations from the letters: 
[After a lunch at a colleague's home], I found in utter shock that all the four hubcaps from my near-new Mitsubishi sedan were missing. I was pretty annoyed and told my host that his house was located in a rough suburb that was full of thugs and thieves of motor car parts! ... You expressed your genuine sympathy to me!...[I]magine my surprise when the day after the incident, Ken Clements gave me the hubcaps back and said that you, Larry Sjaastad, Professor of Economics at The University of Chicago, had planned the entire prank!

Robin Ghosh

I will never forget the day I gave my thesis seminar, and the party that followed that night... That night a large group of your students, friends and their spouses gathered in the party room located in the top floor of the building in South Shore Drive where Luis and Maria Antonieta Durán lived. The party went on until early in the morning, 5.00-6.00 am, of the following day. When you proposed to continue the party at your house to those of us still standing, precariously I would say, we gladly accepted. I remember entering the elevator with you and others and, to our surprise, you started pushing all the buttons on the way down. We thought you were out of your mind, but what you did after that surprised us even more. When the elevator stopped in each floor, you would come out, run through the corridor and ring the bells of the apartments in the floor. We arrived safely at the lobby and left unscathed for your house.

Jorge García-García

[In about 1987 you visited] Monash University's Centre of Policy Studies, en route to the University of Western Australia. The arrangement was that you would stay at my house, which was close to the campus. My recollection is that you arrived at about 9.00am, jet-lagged off the grueling trans-Pacific flight. Keen to try to repay at least some of the generosity and hospitality I had received in many different forms from the Chicago faculty, and to get first-hand news of the Department, I (for some retrospectively unaccountable reason) suggested we have a beer. I think I detected some surprise, but you nevertheless went along with the suggestion, possibly taking it to be a quaint Australian ritual. (I'm pretty certain I hadn't previously started drinking beer at that hour since my undergraduate days at the University of Western Australia.) Be that as it may I, at least, enjoyed immensely the ensuing few hours of conversation over quite 
a few beers. So much so that I completely lost sight of the fact that you were scheduled for a $1 \mathrm{pm}$ lunch followed by a $3 \mathrm{pm}$ seminar. During the seminar I suffered wave after wave of remorse as I watched you struggle valiantly (and remarkably successfully) to stay focused. But my suffering must have been as nothing compared with yours. It could only have been the early conditioning in the Dakota wheat fields that got you through that afternoon.

Geoff Hogbin 


\section{APPENDIX}

\section{TABLE}

\section{PHD STUDENTS SUPERVISED AT CHICAGO BY LARRY SJAASTAD}

\begin{tabular}{|c|c|c|}
\hline Name & Year & Thesis Title \\
\hline 1. Abrantes-Metz, Rosa Maria & 2002 & Before and After the EMU: Financial Integration, Monetary Policy and Welfare Changes \\
\hline 2. Ackerman, Glenn & 1994 & Renters, Homeowners, Politics, and Tiebout \\
\hline 3. Aguilera, Nelly & 2000 & Measuring Aggregate Price Levels \\
\hline 4. Almansi, Aquiles & 1986 & Essays on Incentive Problems in International Credit Markets \\
\hline 5. Almonacid, Ruben D. & 1971 & Nominal Income, Output and Prices in the Short Run \\
\hline 6. Annunziato, Paolo & 1992 & Pricing Practices in Markets With Product Differentiation: The Case of the Automobile Industry in Europe \\
\hline 7. Ardito, Nicolas & 1971 & Costs and Social Benefits of Agricultural Research in Mexico \\
\hline 8. Auernheimer, Leonardo & 1973 & Essays of the Pure Theory of Inflation \\
\hline 9. Avishur, Arieh & 1994 & The Effect of the Privatization of British Telecom on Efficiency; A Dual Approach \\
\hline 10. Balino, Tomas T. T. & 1977 & Argentine Monetary and Banking Reform of 1946 \\
\hline 11. Baranes, Amos & 1989 & Changes in the Tax Saving From Taxable Acquisitions and Tax-Free Reorganization Over Time \\
\hline 12. Barcinski, Alexandre & 2001 & An Empirical Investigation of the Secondary Market of Sovereign Bonds \\
\hline 13. Bender, Bruce & 1976 & The Determinants of Housing Abandonment \\
\hline 14. Bender, John & 1985 & Technology, Unskilled Labor, and the Decline of New England Cotton Textiles \\
\hline 15. Bolanos, Rodrigo & 1982 & Optimal Operation and Investment in a Predominantly Hydroelectric System With Water Storage Capacity \\
\hline 16. Burns, Joseph M. & 1967 & The Real Sector in a Theory of Finance With Special Emphasis on Financial Innovation, the Costs of Finance, and Economic Growth \\
\hline 17. Byerts, William & 1975 & Panama and the World Inflation \\
\hline 18. Canales-Kriljenko, Jorge Ivan & 1996 & The Peruvian Hyperinflation \\
\hline 19. Castaneda, Tarsicio & 1979 & Fertility, Child Schooling and the Labor Force Participation of Mothers in Colombia, 1977 \\
\hline 20. Carstens, Agustin & 1985 & A Study on the Mexico Peso Forward Exchange Market \\
\hline
\end{tabular}


TABLE 1 (Continued)

\section{PHD STUDENTS SUPERVISED AT CHICAGO BY LARRY SJAASTAD}

\begin{tabular}{|c|c|c|c|}
\hline & Name & Year & Thesis Title \\
\hline 21. & Carvalho, Jose & 1972 & Production, Investment and Expectations: A Study of the United States Cattle Industry \\
\hline 22. & Chang, Keun Ho & 1994 & A Model of the Tax Structure of U. S. State Government \\
\hline 23. & Chen, Chau - Nan & 1970 & Flexible Bimetallic Exchange Rates and Optimum Currency Areas: A Theory of Bimetallism \\
\hline 24. & Cheng, Kevin & 2002 & Economic Implications of China's Population in the 21st Century \\
\hline 25. & Choi, Soon-Young & 2002 & The Chonsei Housing Rental Market of Korea \\
\hline 26. & Chua, Vicent & 1989 & Estimating Congestion and Scale Economies for Public Goods \\
\hline 27. & Chun, Suk-Kyu & 1995 & Trade Liberalization, Capital inflows, and Economies of Scale: A General Equilibrium Approach \\
\hline 28. & Clements, Kenneth W. & 1977 & The Trade Balance in Monetary General Equilibrium \\
\hline 29. & Corbo, Mario & 1974 & Schooling Experience and Wages in Santiago, Chile \\
\hline 30. & Cordomi, Manuel & 1969 & A Study of the Production of Sugar in Tucuman, Argentine \\
\hline 31. & Damus, Roberto S. & 1979 & A Two-Part Ramsey-Optimum Railroad Tariff \\
\hline 32. & Della-Paolera, Gerardo & 1988 & How the Argentine Economy Performed During the International Gold Standard: A Reexamination \\
\hline 33. & De Nicola, Carlo & 1995 & The Benefits of Economic Integration Among European Countries \\
\hline 34. & Devereux, John & 1989 & The Incidence of Commercial Policy in Developing Countries: Theory and Evidence \\
\hline 35. & Dick, Andrew & 1989 & Imperfect International Competition in Innovation and Product Markets: Theoretical Implications With an Empirical Application \\
\hline 36. & Dougan, William R. & 1981 & The Political Economy of Protection \\
\hline 37. & Durkin, John & 1991 & Theory and Evidence on Scale, Trade, Structural Change and Economic Development \\
\hline 38. & Elias, Victor J. & 1969 & Estimates of Value Added, Capital and Labor in Argentine Manufacturing 1935-1963 \\
\hline 39. & Erceg, Christopher & 1993 & A Dynamic General Equilibrium Model of the Housing Market \\
\hline 40. & Fernandez, Carlos & 1999 & Inflation and Welfare in an Endogenously Growing Economy \\
\hline
\end{tabular}

(Continued on next page) 
TABLE 1 (Continued)

\section{PHD STUDENTS SUPERVISED AT CHICAGO BY LARRY SJAASTAD}

\begin{tabular}{|c|c|c|c|}
\hline & Name & Year & Thesis Title \\
\hline 41. & Fontaine, Ernesto & 1964 & The Sugar Beet Industry in Chile: A Cost Benefit Analysis \\
\hline 42. & French-Davis, Richardo & 1971 & Economic Policies and Stabilization Programs, Chile 1952-1969 \\
\hline 43. & Garcia, Valeriano F. & 1973 & A Critical Inquiry into Argentine Economic History, 1946-1970 \\
\hline 44. & Garcia, Daniel David & 1998 & The Argentine Labor Market: History and Theory \\
\hline 45. & Garcia-Garcia, Jorge & 1976 & A History of Economic Policies in Colombia: 1953-1970 \\
\hline 46. & Ge, Zening & 1996 & Real Growth Targeting, Money Supply and Fluctuations in the Transitional Chinese Economy \\
\hline 47. & Genel, Julio A. & 1977 & On the State's Strategy for Financial Development: The Problem of Noninflationary Financing in Mexico \\
\hline 48. & Gil Diaz, Francisco & 1982 & Three Essays on the Taxation of Capital \\
\hline 49. & Godek, Paul & 1983 & Aspects of the Positive Theory of Trade Restrictions \\
\hline 50. & Gomez, Javier & 1995 & Three Cases Studies on Exchange Rates \\
\hline 51. & Gonclaves, Antonio & 1974 & The Problem of Stopping Inflation \\
\hline 52. & Gressel, Daniel & 1984 & The Effects of Trade Policy, Size of Government and Inflation on Growth Rates in Less Developed countries \\
\hline 53. & Griffes, Peter Hoyt & 1993 & Risk Sharing in Electricity Generation: The Case of Jointly Owned Plants \\
\hline 54. & Guedes, Paulo & 1978 & Fiscal Policy, Public Debt and External Indebtness in Non-Monetary Two Sector Open Growth Models \\
\hline 55. & Gutierrez, Mario & 1987 & Essays of the System of National Accounts in LDC's \\
\hline 56. & Hachette, Dominique & 1973 & Revaluation of the Escudo and Distribution of Income \\
\hline 57. & Hansen, Ronald & 1982 & Cost and Benefits of Innovation and Regulation in the Pharmaceutical Industry \\
\hline 58. & Haroun, Mansour & 1994 & Mortgage Choice and Asset Pricing \\
\hline 59. & Harvath, Michael & 1994 & The Use of Categorical Programs for Income Redistribution \\
\hline 60. & Hernandez, Lilana & 2001 & Sterilization of Capital Inflows: Its Impact on Market Liquidity and Currency Collapses \\
\hline
\end{tabular}




\section{TABLE 1 (Continued)}

\section{PHD STUDENTS SUPERVISED AT CHICAGO BY LARRY SJAASTAD}

\begin{tabular}{|c|c|c|c|}
\hline & Name & Year & Thesis Title \\
\hline 61. & Hernandez, Luis Mario & 2000 & An Essay on City Sizes and Urbanization Processes \\
\hline 62. & Hsu, David & 1995 & Inter-Area Differences in Wages: Theory and Evidence \\
\hline 63. & Hur, Seok-kyun & 2002 & Two Essays in Financial Decision-Making \\
\hline 64. & Hurtado, Carlos & 1986 & The Real Exchange Rate and Its Relationship to Capital Flows, Public Deficits, and Portfolio Choice in a Small Economy \\
\hline 65. & Johnson, Andrew & 1997 & Taxation and Economic Growth: An International Comparison \\
\hline 66. & Joun, Han Gun & 1994 & Family Member Quality and Housing Demand \\
\hline 67. & Juan Ramon, V. Hugo & 1988 & External Shocks and Fluctuations in the Domestic Real Rate of Interest \\
\hline 68. & Kahn, Peter & 1981 & Short Run Effects of Trade Liberalization \\
\hline 69. & Kim, Chong Sup & 1991 & Deficits, Debt Capitals, Flight, and Finite Horizons--An Exercise in the Theory of the Second Best \\
\hline 70. & Kim, Inchul & 1981 & A Partial Adjustment Approach to the Balance of Payment in Korea: Theory and Evidence \\
\hline \multicolumn{4}{|r|}{ ( } \\
\hline 71. & Kim, June Dong & 1991 & The Incidence of Protection: The Korean Case and Some International Comparisons \\
\hline 72. & Kitti, Carole & 1973 & Patent Policy and the Optimal Timing of Innovations \\
\hline 73. & Koerner, Craig Martin & 2000 & Explaining Industry Level $R$ and D Expenditures with a Stock of Knowledge Variables \\
\hline 74. & Le, Thuan-nghi & 1997 & Co-Movements Between Consumption and Output Growth in the Open Economy \\
\hline 75. & Lee, Shi Young & 1994 & Essays on the Latin American Debt Crisis \\
\hline 76. & Lee, Taiki & 2000 & The Asian Crisis and Stock Market Co-Movements: The US Market Effects on the Korean and Japanese Markets \\
\hline 77. & Lee, Ungkeun Augustine & 1996 & Factor Mobility and the Demand for Trade Liberalization in the United States \\
\hline 78. & Lefton, Norman & 1972 & The Demand for Real Cash Balances and the Expected Permanent and Contemporaneous Rates of Inflation \\
\hline 79. & Liao, Szu-Lang & 1994 & Real Estate Investment and Pricing: The Role of Transaction Costs \\
\hline 80. & Lizondo, Jose & 1979 & Three Essays in International Economics \\
\hline
\end{tabular}


TABLE 1 (Continued)

\section{PHD STUDENTS SUPERVISED AT CHICAGO BY LARRY SJAASTAD}

\begin{tabular}{|c|c|c|c|}
\hline & Name & Year & Thesis Title \\
\hline 81. & Lo Passo, Francesco & 1994 & Italian State Owned Enterprises: An Empirical Study of Changes in Agency Cost \\
\hline 82. & Longoni, Carlos & 1970 & A Study in Economic Growth: The Brazilian Case \\
\hline 83. & Loser, Claudio & 1971 & The Intensity of Trade Restrictions in Argentina: 1939-68 \\
\hline 84. & Luders, Rolf & 1968 & A Monetary History of Chile: $1925-58$ \\
\hline 85. & Mankin, Wyatt & 1971 & Home Ownership and Race \\
\hline 86. & Marquez -Ruarte, Jorge & 1975 & The Two-Sector Model of Production \\
\hline 87. & Martinez, Miguel E. & 1970 & The Trans-Andean Highway: A Cost-Benefit Case Study \\
\hline 88. & May, Josef & 1968 & An Adjustment Mechanism Based on Anticipations in a Macro-Economic Model \\
\hline 89. & McGrew, Wesley & 1988 & Budget Deficits in an Open Economy: Effects on Real Exchange Rates, Interest Rates, and Investment \\
\hline 90 . & Medina, Juan Jorge & 1987 & Protection, True Protection, and Aggregate Protection \\
\hline 91. & Metz, Albert & 2002 & Estimating the Tax Shelter Value of Commercial Office Real Estate: Consequence of the Tax Reform Act of 1986 \\
\hline 92. & Miller, Suzanne & 1996 & Public-Private Competition: The Case of Phoenix \\
\hline 93. & Milner, Humphrey H. & 1975 & Puerto Rican Growth: A Two-Stage CES Production Function \\
\hline 94. & Miranda, Kenneth & 1986 & Manufactured Export Performances in Developing Countries: A Sectoral Trade Model Approach \\
\hline 95. & Moura, Marcelo & 2000 & An Essay on the Effects of Government Deficits on Equilibrium Real Exchange Rates and Stock Prices \\
\hline 96. & Mudd, Shannon & 1994 & The Structure of Trade in a Model of Quality-Differentiated Goods and Human Capital \\
\hline 97. & Musalem, Alberto R. & 1971 & The Demand for Money and the Balance of Payments of Colombia, 1950-1966 \\
\hline 98. & Nielson, Mark & 1993 & Investigation Costs and the Effects of Own Variance on Security Prices \\
\hline 99. & Noer, John & 1988 & Essays on International Arbitrage and Market Efficiency \\
\hline 100. & Novaes, Rudem & 1974 & Foreign Investment in Brazil - An Economic Analysis \\
\hline
\end{tabular}

(Continued on next page) 
TABLE 1 (Continued)

\section{PHD STUDENTS SUPERVISED AT CHICAGO BY LARRY SJAASTAD}

\begin{tabular}{|c|c|c|c|}
\hline & Name & Year & Thesis Title \\
\hline 101. & Pang, Xinbang & 2003 & Two Essays on Foreign Trade in China \\
\hline 102. & Panzer, John & 1989 & Aspects of the Political Economy of Protection \\
\hline 103. & Petrei, Amalio H. & 1971 & Rates of Return to Physical Capital in Manufacturing Industries in Argentina \\
\hline 104. & Pou, Pedro & 1978 & Money and the Balance of Payments: The Experience of Argentina and Brazil \\
\hline 105. & Rapoport, Alan & 1975 & The Protective Policies of Panama: An Empirical Study \\
\hline 106. & Reca, Lucio G. & 1967 & The Price and Production Duality Within Argentine Agriculture, 1923-1965 \\
\hline 107. & Riboud, Mischelle & 1977 & An Analysis of Earnings Distribution in France \\
\hline 108. & Rivera, Luis A. & 1992 & Essays on Trade, Techniques, and Economic Growth \\
\hline 109. & Saieh, Alvaro & 1980 & Behavior of Monetary Variables in Fixed Exchange Rate Economics \\
\hline 110. & Sanchez, Fernando & 1983 & Tax Incentives to Investment for the Promotion of Industry: The Mexican Experience \\
\hline 111. & Sapelli, Claudio & 1985 & Government Policy and the Uruguayan Beef Sector \\
\hline 112. & Scacciavillani, Fabio & 1993 & Long Memory Processes in Speculative Markets \\
\hline 113. & Schenone, Osvaldo & 1973 & A Dynamic Analysis of Taxation \\
\hline 114. & Schickele, Sandra & 1977 & The Social Opportunity Cost of Urban Labor in the United States \\
\hline 115. & Schwartz, Aba & 1968 & Migration and Life Span Earnings in the U.S. \\
\hline 116. & Selowsky, Marcelo & 1967 & Education and Economic Growth: Some International Comparisons \\
\hline 117. & Shampine, Allan & 1996 & An Evaluation of Technology Diffusion Models and Their Implications \\
\hline 118. & Sowell, Thomas & 1968 & Say's Law and the General Glut Controversy \\
\hline 119. & Tao, Ran & 2002 & Urban and Rural Household Taxation in China: Measurement, Economic Analysis and Policy Implications \\
\hline 120. & Tcha, MoonJoong & 1992 & Altruism and Migration--Korea and the United States \\
\hline
\end{tabular}


TABLE 1 (Continued)

PHD STUDENTS SUPERVISED AT CHICAGO BY LARRY SJAASTAD

\begin{tabular}{|c|c|c|c|}
\hline & Name & Year & Thesis Title \\
\hline 121. & Teubal, Morris F. D. & 1967 & Inflation, Unemployment and Economic Growth \\
\hline 122. & Thomas, Vinod & 1977 & The Welfare Cost of Pollution Control With Special Alternatives \\
\hline 123. & Toribio, Juan Jose & 1970 & On the Monetary Effects of Repressed Inflation \\
\hline 124. & Tullio, Giuseppe & 1977 & Monetary Equilibrium and Balance of Payment Adjustment: An Empirical Test of the U. S. Balance of Payments \\
\hline 125. & Verstraete, Juan & 1975 & An Investment Function for Belgium \\
\hline 126. & Viana, Luis & 1987 & Real Exchange Rates and Real Interest Rates During Liberalization, Boom, and Crisis: The Cases of Uruguay and Chile, 1976-82 \\
\hline 127. & Videla, Pedro Luis & 1994 & Stabilization Policies for a Small Economy in a World of Flexible Exchange Rates \\
\hline 128. & Visaruthvong, Chonlathan & 1997 & Tax Evasion and Penalty Structure \\
\hline 129. & Vora, Ankur & 2003 & Impact of Foreign Direct Investment on Developing Country Credit Markets \\
\hline 130. & Wada, Kenji & 1999 & Essay in Public Finance \\
\hline 131. & Wisecarver, Daniel & 1974 & Three Essays in the Theory of Applied Welfare Economics \\
\hline 132. & Yelten, Sibel & 2000 & Real Effects of Movements in Nominal Exchange Rates \\
\hline 133. & Yepez G., Rigoberto Ariel & 1995 & Pricing Policies for the Natural Gas Industry in Mexico \\
\hline 134. & Yoshino, Joe Akira & 1993 & Money and Banking Regulation: The Welfare Costs of Inflation \\
\hline 135. & Yuravlivker, David & 1982 & The Real Exchange Rate in Developing Countries \\
\hline 136. & Yver, Raul & 1971 & The Investment Behavior and the Supply Response of the Cattle Industry in Argentina \\
\hline 137. & Zablotsky, Edgardo & 1992 & The Economic Theory of Autocracy: A Public Good Approach to Military Coups d'Eat \\
\hline 138. & Zapata, Juan & 1970 & Externalities and Ground Water Use \\
\hline 139. & Zhan, Shiqiang & 2000 & Trends in Regional Disparities and Economic Growth in China \\
\hline
\end{tabular}




\section{REFERENCES}

Clements, K. W. and M. Tcha (2004a). "The Larry Sjaastad Letters, I." Discussion Paper No 04.15, Economics Program, The University of Western Australia. Available at http://www.econs.ecel.uwa.edu.au/erc/erc/2004/larrysbook.pdf

(2004b). "The Larry Sjaastad Letters, II." Discussion Paper No 04.16, Economics Program, The University of Western Australia. Available at http://www.econs.ecel.uwa.edu.au/erc/erc/2004/larrysbook.pdf

Sjaastad, L. A. (1962). "Costs and Returns of Human Migration." Journal of Political Economy Vol. 70, No. 5: 80-93.

(1977). "The Social Cost of Public Finance" (with D. Wisecarver). Journal of Political Economy Vol. 85, No. 3: 513-48.

(1980). "Commercial Policy, 'True Tariffs' and Relative Prices." In J. Black and B. Hindley (eds) Current Issues in Commercial Policy and Diplomacy. St Martins Press: New York.

(1989). "Debt, Depression, and Real Rates of Interest in Latin America." In P. L. Brock, M. Connolly and C. Gonzalez-Vega (eds), Latin American Debt and Adjustment. Praeger: New York.

(1990). "Exchange Rates and Commodity Prices: The Australian Case." in K. W. Clements and J. Freebairn (eds), Exchange Rates and Australian Commodity Exports. Center for Policy Studies, Monash University: Clayton, Vic.

(1996). "The Price of Gold and the Exchange Rates" (with F. Scacciavillani). Journal of International Money and Finance Vol. 15, No. 6: 87997. Reprinted in M. Manzur (ed), Exchange Rates, Interest Rates and Commodity Prices. Edward Elgar: Cheltenham UK and Northampton, Mass, 2002; and in M. Tcha (ed), Gold and the Modern World Economy. Routledge: London and New York, 2003.

(1998a). "On Exchange Rates, Nominal and Real." Journal of International Money and Finance Vol 17, No. 3: 407-39. Reprinted in M. Manzur (ed), Exchange Rates, Interest Rates and Commodity Prices. Edward Elgar: Cheltenham UK and Northampton, Mass, 2002.

(1998b). "Why PPP Real Exchange Rates Mislead." Journal of Applied Economics Vol. 1, No. 1: 179-207.

(1999). "Exchange Rate Management Under the Current Tri-Polar Regime" (Lim Tay Boh Lecture, September 1998, National University of Singapore). Singapore Economic Review Vol. 43, No.1: 1-9. 
Sjaastad, L. A. (2000). "Exchange Rate Strategies for Small Countries." Zagreb Journal of Economics Vol. 4, No. 6: 46-51.

(2001). "Some Pitfalls of Regionalization." The Journal of the Korean Economy Vol. 2, No. 2.

(2003). "Import Protection, Capital Inflows and Real Exchange Rate Dynamics" (with M. Manzur). Journal of Applied Economics Vol. 6, No.1: 177203. 